whole of the North Atlantic between ca. $25^{\circ}$ and ca. $45^{\circ}$ N.L. Of these the specimens from west of ca. $20^{\circ} \mathrm{W}$. were the smallest in size, namely, $3^{1 /}-6 \mathrm{~cm}$.

To make quite certain of the forms we were dealing with, it has been necessary to examine thousands of eels, not only from the continents, but also from all the Atlantic islands where the eel occurs (Iceland, Faeroes, Madeira, Canaries, Azores, Bermudas, and the West Indies). The result is also shown on Fig. 2. There are only two species of eel in the North Atlantic region, an eastern (A. vulgaris), which has its western limit at the Azores, and a western (A. rostrata). A further result has been that the stocks are practically unmixed, each being restricted to its own region. On counting the vertebræ (myomeres) in cur larvæ from the Atlantic, we were now able to prove that only the larvæ taken west of the Bermudas belonged to $A$. rostrata, whilst larvæ of A. vulgaris were found in large quantities as far west as $53^{\circ}$ W.L.- - though, as mentioned, the western limit of the adult is at the Azores, ca. $30^{\circ} \mathrm{W}$. The larvæ may even occur further west.

The question is, now, whether we can prove that the smaller larvæ $\left(3 \frac{1}{2}-6 \mathrm{~cm}\right.$.) from the central part of the Atlantic are the product of the main stock of A. vulgaris, which lives on the European continent. It might be thought, for example, that the larvæ found near the Azores come from the stock living on those islands; but, fortunately, we have now obtained from the Gulf Stream south of Newfoundland, $53^{\circ} \mathrm{W}$., such a large number of half-grown larvæ that the quantity alone seems to exclude the possibility that they can spring from the inconsiderable stocks on the Azores or other Atlantic islands. The distance from Europe of the place in the Gulf Stream where they were found, is ca. 2000 miles, but there can be no doubt that they traverse this distance with the currents, for we have found the intermediate stages on the way, and another species, Synaphobranchus pinnatus, whose full-grown larvæ are found in quantities west of Europe in company with those of the eel, has the same distribution.

We see from the Chart and Table how the larvæ of $A$. vulgaris are distributed in a very characteristic manner according to age or size, over the whole of an enormous area, by comparison with which the distances in the Mediterranean seem small. We have not yet attained to the full solution of the exceedingly difficult eel problem, but the steady progress of the last twenty years is full of promise for the future. We cannot say exactly where the eel spawns, though the Sargasso Sea is perhaps a principal spawning region, but continued collections and investigation of the currents will assuredly lead to the discovery of the eggs and earliest larvæ, perhaps not in deep water, as Grassi imagined, but nearer to the surface. There is even perhaps reason to believe that the eel spawns in the intermediate layers and not on the bottom. Altogether, the whole story of the eel and its spawning has come to read almost like a romance, wherein reality has far exceeded the dreams of phantasy.

No. 2234 , VOL. 89?

\section{THE FIFTH INTERNATIONAL CONGRESS} OE MATHEMATICIANS.

[HE International Congress of Mathematicians, which meets in Cambridge on August 22, is the fifth of a series inaugurated at Zürich in 1897 and continued in Paris, Igoo, Heidelberg, 1904, and Rome, 1908. The inviting body is the Cambridge Philosophical Society, and the project of receiving the fifth Congress at Cambridge has been well supported, not only by Cambridge men, resident and non-resident, but also by others, in Oxford and in the country generally, who are interested in the progress of mathematics.

The congress is organised in four sections, deroted respectively to analysis, geometry, applied mathematics, and philosophical, historical, and didactical questions. The Section of Applied Mathematics is divided into two departments, one dealing with mathematical physics and astronomy, and the other with economics and statistics. Each section appoints its own chairman from day to day, the chairman for the first day being chosen by an international committee from among those persons who, in the preparation for the congress, have been charged with the duty of collecting papers for the sections. The sections also appoint their own secretaries. The work of preparation has been in the hands of an organising committee, presided over by Sir George Darwin, and having as treasurer Sir Joseph Larmor, and as secretaries Prof. E. W. Hobson, of Cambridge, and Prof. A. E. H. Love, of Oxford.

Owing to the great interest which is now taken in the study of improved methods of teaching, the department dealing with didactical questions has attracted to the congress many adherents interested in questions concerning the teaching of mathematics. Associated with this department is an international commission appointed at Rome four years ago to collect information in regard to the methods pursued in various countries, and to study the directions and effects of recent changes. In Great Britain the work of collecting this information has been done by an advisory committee of the Board of Education, and the information has been incorporated in a series of reports issued by the Board and now collected in two large volumes. These are intended for presentation to the congress, and similar reports have been compiled with the same view in Germany and the other countries.

In addition to the sectional meetings of the congress, there will be plenary sessions, at which lectures will be delivered, as follows :- "Boundary problems in one dimension," by Prof. M. Bôcher. of Harvard; "Définition et domaine d'existence des fonctions monogènes uniformes," by Prof. E. Borel, of Paris ; "Periodicity in the solar system," by Prof. E. W'. Brown, of Yale; "Il significato della critica dei principii nello sviluppo delle matematiche," by Prof. F. Enriques, of Bologna; "The principles of instrumental seismology," by Prince B. Galitzin, of St. Petersburg; "Gelöste und ungelöste Probleme aus der Theorie der Primzahlverteilung und der Riemannschen Zeta-
JoHs. ScHMIDT. Primzahlve 
funktion," by Prof. E. Landau, of Göttingen; "The dynamics of radiation," by Sir J. Larmor; "The place of mathematics in engineering practice," by Sir W. H. White. The formal opening meeting is to take place this morning, and the formal concluding meeting on the evening of August 27.

Besides the lectures and sectional meetings there will be many opportunities for social intercourse afforded by evening receptions, afternoon parties, and excursions. On the evening of Wednesday, August $2 \mathrm{x}$, the members of the congress were received in the Combination Room and Hall of St. John's College by Sir George Darwin, President of the Cambridge Philosophical Society, and Mr. R. F. Scott, Vice-Chancellor of the University. On the evening of Friday, August 23, they will be received at the Fitzwilliam Museum by Lord Rayleigh, the Chancellor of the University. On Sunday afternoon, August 25, the organising committee will receive the members in the gardens of Christ's College, and in the evening an organ recital will be given in King's College Chapel; also on Monday evening, August 26, there will be a reception in Trinity College by the master and fellows. Facilities will be given for visits to the works of the Cambridge Scientific Instrument-making Company, visitors to which will be entertained by Mrs. Horace Darwin, and to the University Observatory, visitors to which will be entertained by Mrs. Newall. An excursion has been organised to Ely on the Monday afternoon, and for the day after the concluding meeting visits are arranged to Oxford and Hatfield. A committee of ladies, under the presidency of Lady Darwin, has issued a very complete and varied programme of visits to objects of interest in Cambridge for those ladies who accompany members of the congress and may not wish to attend the sectional meetings.

A large concourse is expected, more than 600 persons having already joined or indicated their intention of joining. There are large representations from practically all the countries of Europe, the United States, the British Dominions beyond the seas, Japan, Mexico, and various States of South America. The assembly will thus be truly cosmopolitan, and it is to be hoped that it may prove not less fruitful than the previous assemblies in other countries.

\section{ILLUSTRATIONS OF BRITISH BIRDS.}

THE first part of Mr. Stonham's beautiful work on British Birds ${ }^{1}$ was noticed in these pages on its appearance, and the book has now been completed in twenty parts, forming five handsome volumes printed on pure rag paper, which is not liable to decay or to become discoloured. The beautiful drawings, remarkable for their softness and delicacy, go a long way, at all events, to justify the publishers' claim in the prospectus of the work that they are far superior to anything

I "The Birds of the British Islands." By Charles Stonham, C.M.G. With illustrations by Lilian M. Medland. In zo parts. (London: Grant
Richards, Ltd., Carlton Street, rgo6-19ri). Price 7s. $6 d$. net each part. of the kind yet produced in this country. As a rule, the adult male only of each species is figured, but when the sexes differ in any appreciable degree separate drawings are given. Further, there are additional plates of those nestlings and young birds (as, for example, some waders and gulls) the appearance and plumage of which call for especial illustration, and some winter plumages are given.

The same plan is followed in regard to any particular points of plumage, such as the outspread wing or tail, which the ordinary drawing does not show. Black and white illustration naturally lends itself with most success to those species which have sharply contrasted colours, but it is only in the case of some of those birds which have a large amount of bright chestnut or rufous in their plumage that we have noticed a failure to represent the colour effect adequately. For instance, the knot in summer (P1. 253) is surely much too lightcoloured, and gives little indication of the deep reddish chestnut underparts. The same may be said of the bar-tailed godwit in summer dress. Representing the partridge with the crown of its head of a plain pale colour may have been due possibly to some similar cause. One might, of course, criticise in some other cases minor items from the point of view of the scientific ornithologist, but on the whole there is nothing but high praise for the drawings, and they will entirely satisfy those to whom the work will mainly appeal, viz. the lover of birds, to whom, as to the author himself, they have long afforded so much pleasure and recreation.

It would be invidious to point to any plates especially remarkable for their beauty, but all bird-lovers, according to their individual taste, will surely, as we have done, find some which will be to them a joy for ever. But there are some of especial interest and value. Among these may be mentioned that of five ruffs in their varied liveries, and the remarkable attitudes assumed by them when on the "hill," and the downy nestling of the bar-tailed godwit, drawn from the specimen obtained by Mr. Popham on the Yenesei. Moreover, visitors to the Zoological Gardens in London in 1907 will be deeply grateful to the artist for preserving the pretty and interesting scene of the avocet nestling her young one in her own peculiar manner.

Though the letterpress is necessarily largely a compilation, the author has had very considerable experience as a field observer, and his personal observations will be read with great interest, not the less because the personal experiences of one field ornithologist so often differ a little from those of another; we cannot have too many of these original remarks, for herein lies much of the charm of the study. Here, for instance-to refer to one little thing only-we find that the clutch of eggs of the corn and yellow buntings is said to number from four to six; yet other observers (whose experience was perhaps gained in a different part of the country) we know would put the usual number at three or four only. The descriptions of the 